\title{
Allometric equations for estimating biomass of community forest tree species in Madiun, Indonesia
}

\author{
PANDU YUDHA ADI PUTRA WIRABUANA ${ }^{1, \vartheta}$, RAHMANTA SETIAHADI ${ }^{2, v \vee}$, RONGGO SADONO $^{1}$, \\ MARTIN LUKITO ${ }^{2}$, DJOKO SETYO MARTONO ${ }^{2}$, JERIELS MATATULA ${ }^{3}$ \\ ${ }^{1}$ Department of Forest Management, Faculty of Forestry, Universitas Gadjah Mada. J1. Agro No. 1, Bulaksumur, Sleman 55281, Yogyakarta, Indonesia \\ Tel./fax.: +62-274-548815, `email: pandu.yudha.a.p@ugm.ac.id \\ ${ }^{2}$ Department of Agrotechnology, Faculty of Agriculture, Universitas Merdeka Madiun. Jl. Serayu No.79, Pandean, Taman, Madiun 63133, East Java, \\ Indonesia. Tel./fax.: +62-351-464427, "^email: rahmanta_setiahadi@unmer-madiun.ac.id \\ ${ }^{3}$ Forestry Field Program, Politeknik Pertanian Negeri Kupang. J1. Prof. Herman Johanes, Lasiana, Kupang 85011, East Nusa Tenggara, Indonesia
}

Manuscript received: 12 July 2020. Revision accepted: 25 August 2020.

\begin{abstract}
Wirabuana PYAP, Setiahadi R, Sadono R, Lukito M, Martono DS, Matatula J. 2020. Allometric equations for estimating biomass of community forest tree species in Madiun, Indonesia. Biodiversitas 21: 4291-4300. The capability of community forests for offsetting carbon emissions highly depends on their biomass production. Unfortunately, the measurement of tree biomass in community forests using a destructive method is expensive and time-consuming. It is also almost impossible to conduct this method for all trees in the observation area. Therefore, the development of allometric equations is essential to support tree biomass estimation in community forests. This study was designed to construct specific models for predicting individual tree biomass in community forests, located in Madiun, Indonesia. We destructively sampled approximately 120 trees from four different species (30 trees for each species), i.e., Falcataria moluccana, Melia azedarach, Swietenia macrophylla, and Tectona grandis. For every tree sample, the measurement of biomass was conducted in each tree's component, namely roots, stem, branches, and leaves. The allometric equations were developed with regression analysis using predictor variables, like diameter at breast height (D), squared diameter at breast height combined with tree height $\left(D^{2} H\right)$, as well as D and $\mathrm{H}$ separately. Results found that for four species, the mean biomass in the stem was $50.3 \%$, followed by branches $25.4 \%$, roots $15.9 \%$, and leaves $8.3 \%$. The best equation for estimating biomass in every component and total of four species was different. However, our study showed that the equation $\ln \hat{Y}=-3.037+1.430 \ln \mathrm{D}+1.684$ was reliable to estimate total individual tree biomass of four species in the surveyed area since this model had accuracy of $90.8 \%$. Referring to these findings, we recommended the utilization of an allometric equation as an alternative method for facilitating more efficient biomass measurement in the community forests.
\end{abstract}

Keywords: Best model, biomass distribution, carbon emissions, destructive sampling, reliable

\section{INTRODUCTION}

The community forests make a meaningful contribution to the reduction of carbon emissions in the atmosphere at global and regional scales. However, the capacity of community forests as carbon sequesters principally depends on their biomass production (Setiahadi 2017). As one of the important attributes in community forests, biomass accumulation plays a fundamental role in biogeochemical cycles, especially carbon cycle (Chen et al. 2017). Higher biomass production indicates greater carbon storage, since approximately $50 \%$ of biomass is composed of carbon (Latifah et al. 2018; Viera and RodríguezSoalleiro 2019; Wirabuana et al. 2020). Therefore, the scenario of sustainable management in community forests becomes one of the primary focuses related to climate change mitigation.

In the context of global climate change, the quantification of biomass production in community forests is necessary as an indicator to assess carbon storage and forest productivity (Zhang et al. 2017). Unfortunately, the direct measurement of tree biomass in community forests using a destructive method is expensive and timeconsuming. It is also almost impossible to conduct this approach for all trees in the study area. Thus, the development of allometric equations for predicting tree biomass is required to facilitate a more efficient biomass estimation in community forests (Altanzagas et al. 2019). Several studies also confirm that the use of allometric equations is helpful to conduct the estimation of tree biomass rapidly (Nogueira Junior et al. 2014; Nam et al. 2016; Daba et al. 2019). This method also has a potential contribution to predict the biomass change from different observation periods (Kebede and Soromessa 2018).

The construction of allometric models for computing tree biomass in community forests is substantially more difficult than plantation forests. Besides having various species, the community forests also have a high variation in tree growth rates and age distribution (Baral et al. 2018). Therefore, the prediction model in community forests should be reliable to estimate the individual tree biomass from various species. This reliability is important because the accurate biomass estimation in forest levels is principally affected by the high precision of biomass measurement in tree levels. Thus, the allometric models which have good accuracy are highly required for facilitating biomass assessment. Several studies have evidenced the reliability of allometric models for 
estimating biomass from different types of forest. A study conducted in Northeastern China reported that the accuracy level of allometric equations for estimating aboveground biomass of various tree components in various species forests ranged from 83.7 to $97.2 \%$ (He et al. 2018). Another research undertaken in Papua, recorded that the use of allometric models for predicting total aboveground biomass from 8 genera resulted in the accuracy level of approximately $91 \%$ (Maulana et al. 2016). Both literature obviously confirms the capability of allometric equation as a proxy approach to predict biomass accumulation from various species.

This study was designed to develop allometric models for estimating the individual tree biomass in community forests, located in Madiun. It was required to facilitate the rapid assessment of biomass accumulation to encourage the effort of climate change mitigation. Before this study was conducted, no specific equations had been constructed to calculate the individual tree biomass from various species in this area. The specific objectives of our study were: (i) To quantify individual tree biomass in each component and total from various species in community forest; (ii) To assess the relative contribution of each tree component to total individual tree biomass from various species in community forests; (iii) To construct specific allometric models for estimating individual tree biomass in each component and total from various species; (iv) To discover the best allometric equation which is generally reliable to estimate total individual tree biomass for all species in community forests.

\section{MATERIALS AND METHODS}

\section{Study area}

The study area is situated in community forests around Madiun District, East Java Province, Indonesia covering four villages, namely Kuwiran, Morang, Randualas, and Kare. The study site has a geographic position of $7^{0} 41^{\prime} 1.42^{\prime \prime}$ to $7^{0} 45^{\prime} 31.14^{\prime \prime} \mathrm{S}$ and $111^{0} 39^{\prime} 19.27^{\prime \prime}$ to $111^{0} 42^{\prime} 17.30^{\prime \prime} \mathrm{E}$. Topography is relatively flat, having slope level approximately $0-8 \%$. Altitude varies from 100 to $500 \mathrm{~m}$. The mean daily temperature is $29^{\circ} \mathrm{C}$ with average minimum of $25^{\circ} \mathrm{C}$ and maximum of $35^{\circ} \mathrm{C}$. Annual rainfall ranges from $1,554 \mathrm{~mm}$ to $1,754 \mathrm{~mm}$.year ${ }^{-1}$. The majority of rainfall occurs in December and January. Dry period lasts around 5 months from June to October. The air humidity of study area varies from $70.5 \%$ to $85.6 \%$. Soil types are dominated by alfisols which have high clay content, around $39-42 \%$. The level of cation exchange capacity is relatively moderate, ranging from 14 to $28 \%$. Soil acidity is classified as slightly acid, with a $\mathrm{pH}$ of 5.5-6.0 due to the high content of soil organic matter which ranges from $17 \%$ to 23\% (Setiahadi 2017).

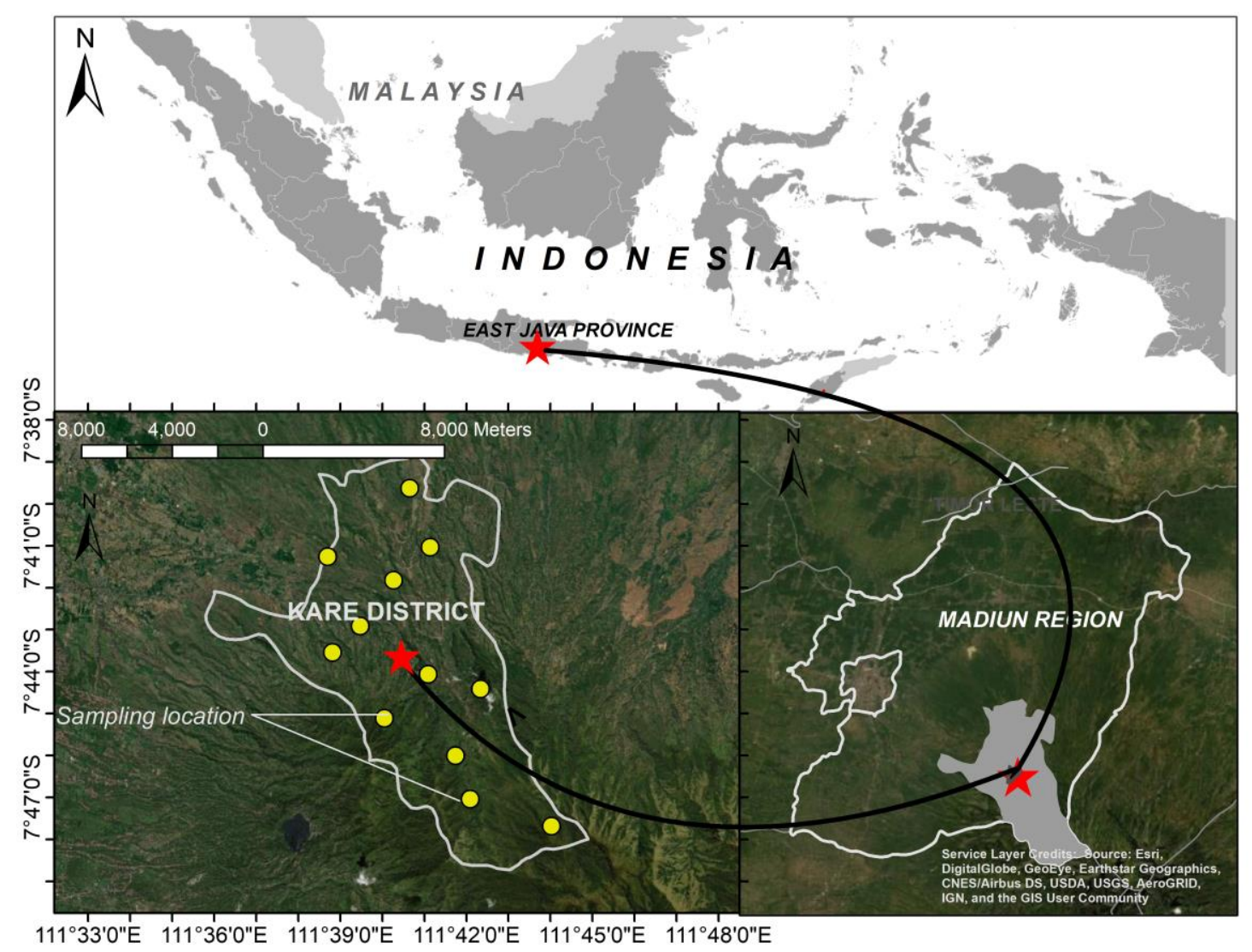

Figure 1. Distribution of sampling locations for measuring tree biomass in each component and total from various species in community forests, Madiun, East Java, Indonesia 


\section{Data collection}

We destructively sampled 120 trees consisting of four different species, i.e. Falcataria moluccana, Melia azedarach, Swietenia macrophylla, and Tectona grandis. Those were the species of trees mostly planted by societies in community forests around Madiun District because of their prospective economic values (Setiahadi 2017). Total sample trees for each species were 30 (Table 1). The sample trees were selected by considering the diameter distribution to obtain the balance growth dimension from small trees to the big ones (Guendehou et al. 2012). We classified trees' diameter into four different classes (Table 2), i.e. smaller than $10 \mathrm{~cm}, 10-20 \mathrm{~cm}, 21-30 \mathrm{~cm}$, and bigger than $30 \mathrm{~cm}$ (Altanzagas et al. 2019).

The process of destructive sampling was implemented step by step in a chronological manner. After the selected trees were felled, the tree components were separated into stem, branches, and leaves. Moreover, the root excavation was also done to record biomass distribution in roots. However, this study was only able to measure the smallest size of root diameter until $5 \mathrm{~cm}$. The fresh weight of every component was measured using a hanging balance in the field. Then, $500 \mathrm{~g}$ sub-sample from each part was taken to the laboratory to be dried (Wirabuana et al. 2019). The drying process was done using an oven at $70^{\circ} \mathrm{C}$ for 48 hours before weighting for biomass determination (Hakamada et al. 2017). Total biomass in each component of sample trees was computed by multiplying the ratio of dry-fresh weight from sub-sample with the total fresh weight of each component which was recorded from the field survey (Hakamada et al. 2017; Altanzagas et al. 2019; Wirabuana et al. 2019).
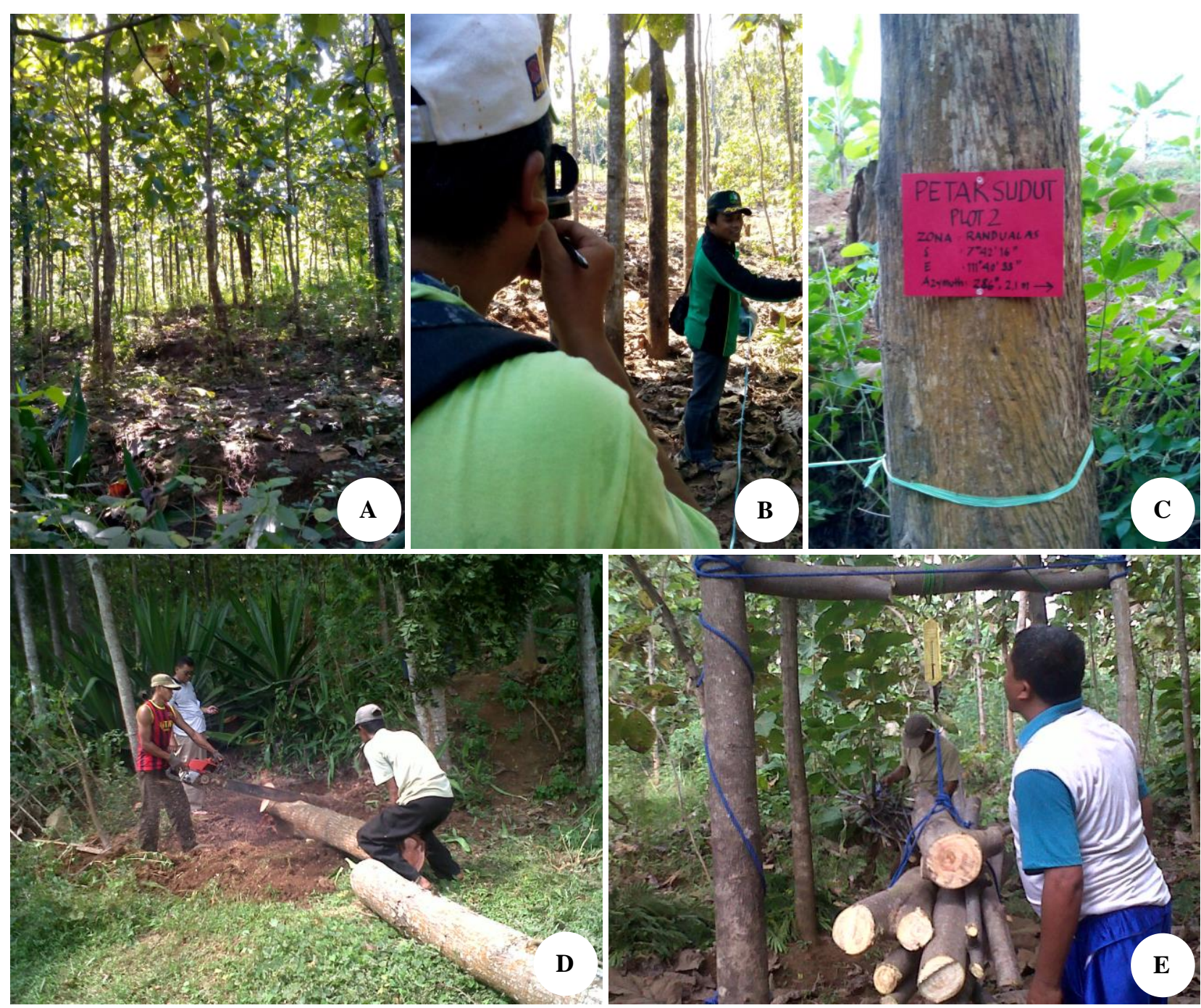

Figure 2. Documentation of data collection process: A. Stand condition in the observation area; B. Designing measurement plot in the field; C. Labeling name tag in each sampling plot; D. Destructive sampling for selected tree; E. Excavating root component 
Table 1. Total sample trees of each species taken from different locations of community forests in Madiun District

\begin{tabular}{lcccc}
\hline Site & \multicolumn{4}{c}{ Number of samples in each species } \\
\cline { 2 - 5 } & $\begin{array}{c}\text { Falcataria } \\
\text { moluccana }\end{array}$ & $\begin{array}{c}\text { Melia } \\
\text { azedarach }\end{array}$ & $\begin{array}{c}\text { Swietenia } \\
\text { macrophylla }\end{array}$ & $\begin{array}{c}\text { Tectona } \\
\text { grandis }\end{array}$ \\
\hline Kuwiran & 7 & 6 & 6 & 9 \\
Morang & 8 & 8 & 7 & 7 \\
Randualas & 7 & 6 & 8 & 7 \\
Kare & 8 & 10 & 9 & 7 \\
\hline Total & 30 & 30 & 30 & 30 \\
\hline
\end{tabular}

Table 2. Number of sample trees in each diameter class from four different species in the study area

\begin{tabular}{lcccc}
\hline \multirow{2}{*}{ Species } & \multicolumn{4}{c}{ Number of sample trees in each diameter class } \\
\cline { 2 - 5 } & $\mathbf{1 0} \mathbf{~ c m}$ & $\mathbf{1 0 - 2 0} \mathbf{~ c m}$ & $\mathbf{2 1 - 3 0} \mathbf{~ c m}$ & $>\mathbf{3 0} \mathbf{~ c m}$ \\
\hline F. moluccana & 5 & 13 & 9 & 3 \\
M. azedarach & 3 & 6 & 10 & 11 \\
S. macrophylla & 3 & 11 & 10 & 6 \\
T. grandis & 5 & 13 & 8 & 4 \\
Total & 16 & 43 & 37 & 24 \\
\hline
\end{tabular}

\section{Data analysis}

The process of data analysis was conducted with $\mathrm{R}$ software version 3.6.1. with a significant level of 5\% using easyreg package (Arnhold 2018). Descriptive test was conducted to identify some data attributes, i.e., minimum, maximum, mean, and standard deviation. Normality of data was assessed using Shapiro-Wilk test. Homogeneity of variance among the relative contribution of every tree component to total biomass was examined with Bartlett's test. Comparison average of biomass in each component was evaluated with ANOVA and followed with HSD Tukey. Then, three general allometric equations were examined for estimating biomass allocation in each component and total of trees by using some different predictor variables, i.e., diameter at breast height (D), squared diameter at breast height $\left(\mathrm{D}^{2}\right)$ combined by tree height $(\mathrm{H})$, as well as D and $\mathrm{H}$ separately (Battulga et al. 2013; Dong et al. 2015; Xue et al. 2016). The measurement unit of $\mathrm{D}$ and $\mathrm{H}$ for each variable was in $\mathrm{cm}$ and $\mathrm{m}$. Those allometric equations are expressed below:

$$
\begin{aligned}
& \hat{Y}=a D^{b} \\
& \hat{Y}=a\left(D^{2} H\right)^{b} \\
& \hat{Y}=a D^{b} H^{c}
\end{aligned}
$$

Where: $\hat{Y}$ is the estimated biomass value in $\mathrm{kg}$ unit and $\mathrm{a}, \mathrm{b}$, and $\mathrm{c}$ are the fitted parameters.

In general, nonlinear models for biomass studies based on arithmetical units do not have constant value of the error variances overall observations in most cases (Zeng and Tang 2012). It is commonly called heteroscedasticity. Thereby, to eliminate the effect of heteroscedasticity, the use of data transformation in natural $\log$-form is frequently conducted to change the nonlinear model into a linear regression when calculating the parameters for equations
(He et al. 2018). Therefore, those above equations are converted into the following models:

$$
\begin{aligned}
& \ln \hat{Y}=\ln a+b \times \ln D \\
& \ln \hat{Y}=\ln a+b \times \ln \left(D^{2} H\right) \\
& \ln \hat{Y}=\ln a+b \times \ln D+c \times \ln H
\end{aligned}
$$

Where: $\ln \hat{Y}$ is the predicted biomass value in the logarithmic unit and lna, b, and c are the fitted parameters

Many studies have adopted a similar method (logtransformed linear regression) for modeling tree biomass (Xue et al. 2016; He et al. 2018; Altanzagas et al. 2019). The allometric models were calculated separately for roots, stem, branches, leaves, and total. The best model was determined by assessing statistical indicators, i.e., coefficient of determination $\left(\mathrm{R}^{2}\right)$, root means square error (RMSE), mean absolute bias (MAB), and Akaike information criteria (AIC). Highest $\mathrm{R}^{2}$ value, smallest RMSE, MAB, and AIC values indicate the best prediction model. The details formula for calculating those statistical indicators are presented below:

$$
\begin{aligned}
& R^{2}=1-\left(\sum(\ln Y-\ln y)^{2} / \sum(\ln Y-\ln \hat{Y})^{2}\right) \\
& R M S E=\left(\sum(\ln Y-\ln \hat{Y})^{2} /(n-p-1)\right)^{0.5} \\
& M A B=\sum(|\ln Y-\ln \hat{Y}|) / n \\
& A I C=n \log (R S S / n)+2 k+((2 k(k+1)) /(n-k-1))
\end{aligned}
$$

where $\ln Y$ is the actual $\log$-transformed biomass, $\ln \hat{Y}$ is the estimated log-transformed biomass from the fitted model, $n$ is the sample size, lny is the mean of the actual log-transformed biomass, $p$ is the number of terms in the model, RSS is the residual sum of squares from the fitted model, and $k$ is the number of parameters.

Because of our small sample size, the validation process was conducted by comparing the best allometric model with other equations from the previous studies. In addition, our study also proposed an additional criterion to select the best model, namely simplicity. This criterion is really important since it would facilitate more efficient forest inventory in community forests particularly related to biomass monitoring. According to a study reported by Setiahadi (2017), the species composition of community forests in Madiun consisted of many tree species which had irregular age distribution pattern. Therefore, it would be better to discover a single equation which is applicable over various species.

\section{RESULTS AND DISCUSSION}

\section{Biomass accumulation in four species of community forests}

Summarized results of the observation documented that the highest average total biomass was recorded in $M$. azedarach $(371.72 \pm 236.05 \mathrm{~kg})$, followed by $T$. grandis $(283.41 \pm 261.06 \mathrm{~kg})$, S. macrophylla $(214.16 \pm 235.93$ $\mathrm{kg})$, and $F$. moluccana $(71.52 \pm 65.30 \mathrm{~kg})$ (Table 3). Furthermore, the greatest mean biomass was discovered in 
the stem $(50.31 \%)$, followed by branches $(25.40 \%)$, roots $(15.96 \%)$, and leaves $(8.33 \%)$ when the four species were combined (Table 4). These results indicated that more than $80 \%$ of tree biomass in the study area were accumulated aboveground. Our study also noted the mean ratio between aboveground and belowground tree biomass in the study site reached 5:1 wherein the quantity of aboveground biomass was considerably higher than that belowground. It was also consistently similar to other studies conducted in different forest regions (Mendoza-Ponce and Galicia 2010; Ekoungoulou et al. 2015; Nam et al. 2016).

The allocation of total tree biomass into the tree components from four species along diameter classes is demonstrated in Figure 3. The biggest biomass proportion was found in the stem for every species, i.e., approximately 43-57\%, but the pattern was not similar for each tree species. In M. azedarach, the contribution of stem biomass to the total tree biomass slightly decreased from $54 \%$ for the smallest-diameter class $(<10 \mathrm{~cm})$ to $48 \%$ for the largest one $(>30 \mathrm{~cm})$ due to extensively greater contribution of branch biomass to the total tree biomass with the increasing diameter classes. The same trend was also noted in $T$. grandis; however, the decline of stem biomass percentage was higher than in $M$. azedarach by approximately $11 \%$. In contrast, the relative contribution of stem biomass to the total individual tree biomass increased by approximately $13 \%$ in F. moluccana and S. macrophylla from the lowestdiameter class to the highest one. Overall, the relative contribution of branches' biomass to total tree biomass increased for the four species with increasing diameter classes. Consequently, the relative contribution of root and leaf biomass from various species declined with the increasing diameter classes. These results indicate that the biomass in each tree component is different for each species (Mate et al. 2014; Zhang et al. 2015; Yue et al. 2018). This process is also affected by specific factors such as site quality and silviculture treatment (RodríguezSoalleiro et al. 2018). For example, the application of pruning can reduce the relative contribution of branches biomass to the total biomass (Velázquez-Martí et al. 2011).

Our study obviously observed that the dimension size of tree diameter had a relationship to the biomass allocation. Moreover, the percentage of leaf biomass also declined rapidly with the increasing tree diameter, which indicated that relatively more biomass was distributed to the trunk for improving growth and accelerating translocation process. It was consistent with the result of previous studies (Zeng and Tang 2012; Dong et al. 2018; $\mathrm{He}$ et al. 2018). Additionally, this study found the proportion of root biomass decreased gradually with the increasing tree diameter in various species. It was caused by natural pruning in root component. Principally, the primary function of root system is to absorb water and nutrient. When the root becomes older, it regenerates naturally to guarantee the continuity of water and nutrient absorption (Jing et al. 2018). This outcome was similar to the previous studies which were implemented in different forest locations (Mendoza-Ponce and Galicia 2010; Maulana et al. 2016; Purwanto et al. 2015; Nam et al. 2016; Altanzagas et al. 2019).

Table 3. Minimum (min), maximum (max), average (mean), and standard deviation (sd) of biomass in each component and total from four tree species at the sampling location

\begin{tabular}{|c|c|c|c|c|c|c|c|c|}
\hline Species & Value & $\begin{array}{l}\mathrm{D} \\
(\mathrm{cm})\end{array}$ & $\begin{array}{l}\mathbf{H} \\
(\mathrm{cm})\end{array}$ & $\begin{array}{l}\begin{array}{l}\text { Roots } \\
\text { (kg) }\end{array} \\
\end{array}$ & $\begin{array}{l}\text { Stem } \\
(\mathrm{kg})\end{array}$ & $\begin{array}{l}\text { Branches } \\
(\mathrm{kg})\end{array}$ & $\begin{array}{l}\begin{array}{l}\text { Leaves } \\
\text { (kg) }\end{array} \\
\end{array}$ & $\begin{array}{l}\text { Total } \\
(\mathrm{kg})\end{array}$ \\
\hline \multirow[t]{4}{*}{ F. moluccana } & $\min$ & 5.4 & 4.6 & 0.69 & 1.67 & 0.56 & 0.39 & 3.31 \\
\hline & $\max$ & 40.1 & 11.1 & 45.07 & 149.27 & 47.74 & 22.84 & 264.92 \\
\hline & mean & 19.7 & 7.3 & 13.47 & 37.45 & 13.74 & 6.85 & 71.52 \\
\hline & $\mathrm{sd}$ & 8.9 & 1.6 & 11.19 & 36.95 & 11.66 & 5.76 & 65.30 \\
\hline \multirow[t]{4}{*}{ M. azedarach } & $\min$ & 6.4 & 6.3 & 2.02 & 11.13 & 5.29 & 2.27 & 20.71 \\
\hline & $\max$ & 42.3 & 16.8 & 103.26 & 405.22 & 288.64 & 52.19 & 849.31 \\
\hline & mean & 26.3 & 10.7 & 43.86 & 180.39 & 121.73 & 25.75 & 371.72 \\
\hline & $\mathrm{sd}$ & 10.1 & 2.8 & 29.23 & 111.60 & 80.40 & 16.11 & 236.05 \\
\hline \multirow[t]{4}{*}{ S. macrophylla } & $\min$ & 8.9 & 4.8 & 2.67 & 12.33 & 5.40 & 0.92 & 22.48 \\
\hline & $\max$ & 40.4 & 13.0 & 171.58 & 392.08 & 272.46 & 23.23 & 859.34 \\
\hline & mean & 19.8 & 8.2 & 39.35 & 101.81 & 65.81 & 7.18 & 214.16 \\
\hline & $\mathrm{sd}$ & 9.6 & 2.2 & 46.55 & 108.38 & 75.17 & 6.39 & 235.93 \\
\hline \multirow[t]{4}{*}{ T. grandis } & $\min$ & 8.9 & 4.8 & 5.05 & 9.52 & 5.18 & 3.00 & 23.28 \\
\hline & $\max$ & 41.4 & 15.6 & 101.39 & 487.04 & 191.78 & 87.17 & 867.38 \\
\hline & mean & 23.4 & 9.0 & 37.44 & 153.24 & 62.40 & 30.34 & 283.41 \\
\hline & $\mathrm{sd}$ & 10.0 & 3.4 & 30.13 & 145.75 & 59.04 & 26.71 & 261.06 \\
\hline \multirow[t]{4}{*}{ Total species } & $\min$ & 5.41 & 4.60 & 0.69 & 1.67 & 0.56 & 0.39 & 3.31 \\
\hline & $\max$ & 42.32 & 16.80 & 171.58 & 487.04 & 288.64 & 87.17 & 867.38 \\
\hline & mean & 22.30 & 8.81 & 33.53 & 118.22 & 65.92 & 17.53 & 235.20 \\
\hline & sd & 9.93 & 2.83 & 33.60 & 120.01 & 72.87 & 19.22 & 238.62 \\
\hline
\end{tabular}



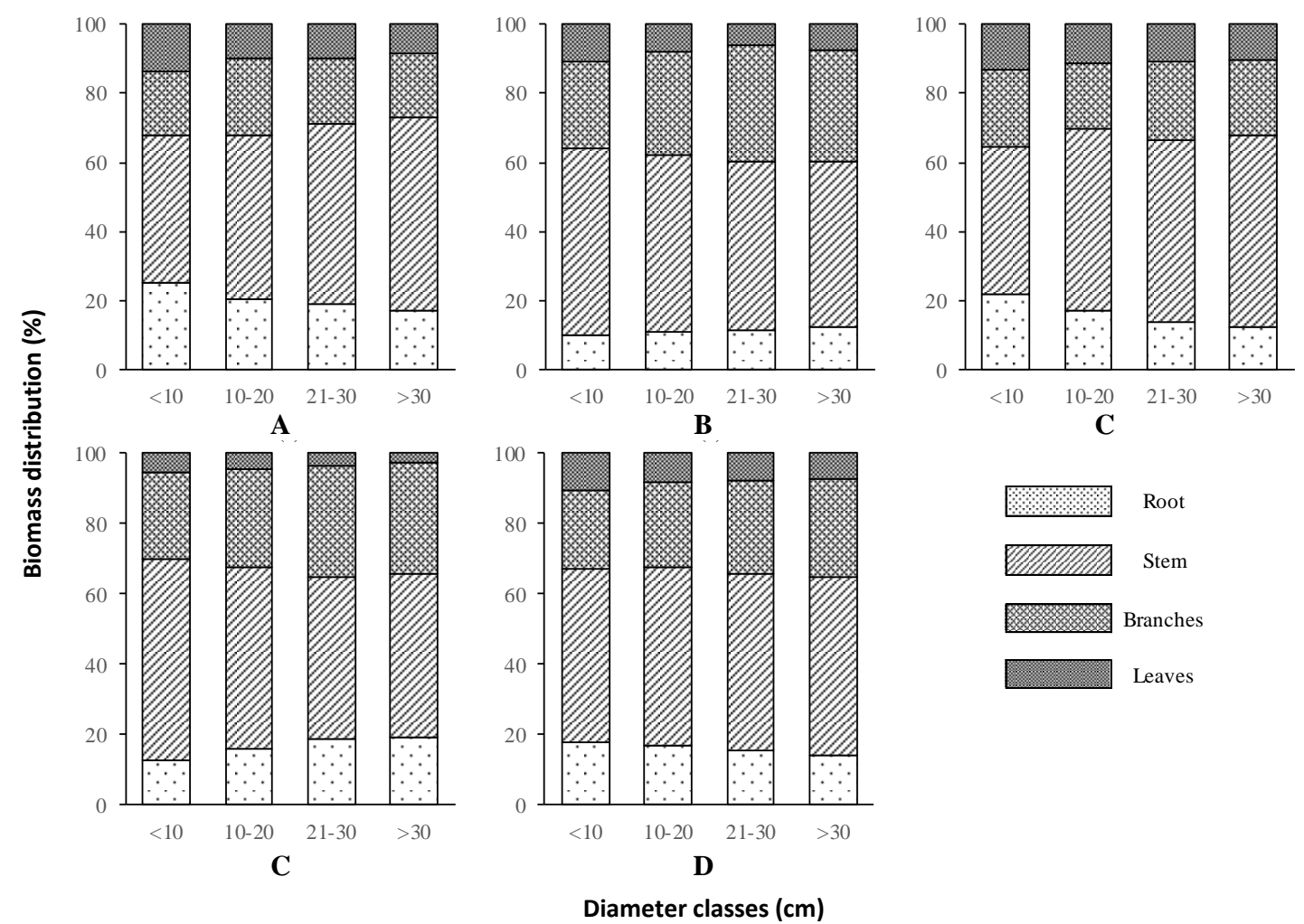

Figure 3. Biomass allocation in tree components across the diameter classes. A. F. moluccana, B. M. azedarach, C. S. macrophylla, D. T. grandis, E. Various species. Data are presented in the percentage unit

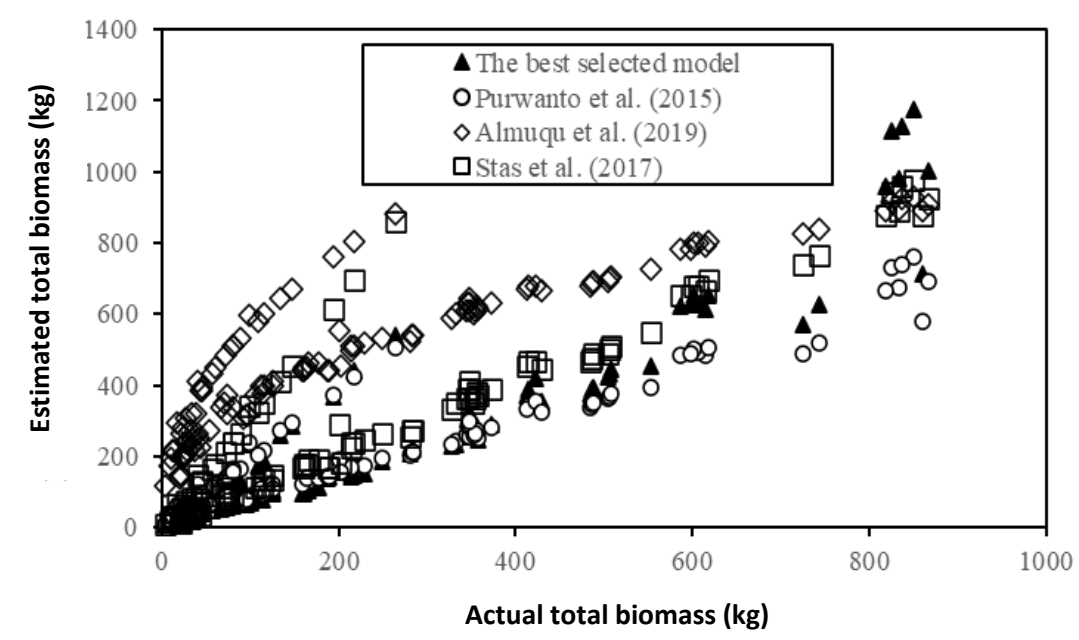

Figure 4. Comparison among the predicted total biomass from the best-selected models for various species and the estimated total biomass using other equations from previous studies

Table 4. Ratio of the biomass of roots, stem, branches, and leaves to the total biomass from sample trees. Data are presented in average (mean) and standard deviation (sd)

\begin{tabular}{|c|c|c|c|c|c|c|c|c|}
\hline \multirow{2}{*}{ Species } & \multicolumn{2}{|c|}{ RB/TB } & \multicolumn{2}{|c|}{ SB/TB } & \multicolumn{2}{|c|}{$\mathrm{BB} / \mathrm{TB}$} & \multicolumn{2}{|c|}{ LB/TB } \\
\hline & mean & sd & Mean & Sd & mean & sd & mean & sd \\
\hline F. moluccana & $20.40 \mathrm{a}$ & 3.17 & $49.07 \mathrm{~b}$ & 5.12 & $20.16 a$ & 5.16 & $10.38 \mathrm{c}$ & 2.23 \\
\hline M. azedarach & $11.42 \mathrm{a}$ & 0.81 & $49.56 b$ & 1.92 & $31.56 \mathrm{c}$ & 2.94 & $7.47 \mathrm{~d}$ & 1.80 \\
\hline S. macrophylla & $15.56 \mathrm{a}$ & 3.24 & $52.15 b$ & 4.58 & $21.12 \mathrm{c}$ & 2.73 & $11.18 \mathrm{~d}$ & 0.95 \\
\hline T. grandis & $16.46 \mathrm{a}$ & 3.14 & $50.45 b$ & 6.69 & $28.79 \mathrm{c}$ & 4.47 & $4.30 \mathrm{~d}$ & 1.67 \\
\hline Total Species & $15.96 \mathrm{a}$ & 4.22 & $50.31 \mathrm{~b}$ & 4.97 & $25.40 \mathrm{c}$ & 6.27 & $8.33 \mathrm{~d}$ & 3.20 \\
\hline
\end{tabular}

Note: root biomass (RB); stem biomass (SB); branch biomass (BB); leaf biomass (LB); total biomass (TB). The similar letter in row indicated the mean value was not significantly different 
Table 5. Summary evaluation statistics of each allometric model for estimating the biomass of roots, stem, branches, and leaves for the four species in the community forests around Madiun District, East Java, Indonesia

\begin{tabular}{|c|c|c|c|c|c|c|c|c|}
\hline Component & Equations* & Lna & b & $\mathbf{c}$ & $\mathbf{R}^{2}$ & RMSE & МАВ & AIC \\
\hline \multicolumn{9}{|l|}{ F. moluccana } \\
\hline \multirow[t]{3}{*}{ Root } & $\ln \hat{Y}=\ln a+b \ln D$ & -3.325 & 1.933 & - & 0.982 & 0.129 & 0.064 & -4.101 \\
\hline & $\ln \hat{Y}=\ln a+b \ln \left(D^{2} H\right)$ & 3.422 & 0.798 & - & 0.974 & 0.156 & 0.110 & -3.651 \\
\hline & $\ln \hat{Y}=\ln a+b \ln D+c \ln H$ & -3.182 & 2.005 & -0.177 & 0.982 & 0.130 & 0.069 & -4.051 \\
\hline \multirow[t]{3}{*}{ Stem } & $\ln \hat{Y}=\ln a+b \ln D$ & -3.451 & 2.284 & - & 0.991 & 0.107 & 0.063 & -4.472 \\
\hline & $\ln \hat{Y}=\ln a+b \ln \left(D^{2} H\right)$ & 4.521 & 0.944 & - & 0.985 & 0.139 & 0.104 & -3.875 \\
\hline & $\ln \hat{Y}=\ln a+b \ln D+c \ln H$ & -3.426 & 2.296 & -0.031 & 0.991 & 0.109 & 0.063 & -4.406 \\
\hline \multirow[t]{3}{*}{ Branches } & $\ln \hat{Y}=\ln a+b \ln D$ & -3.664 & 2.041 & - & 0.907 & 0.324 & 0.169 & -2.258 \\
\hline & $\ln \hat{Y}=\ln a+b \ln \left(D^{2} H\right)$ & 3.464 & 0.845 & - & 0.903 & 0.330 & 0.201 & -2.152 \\
\hline & $\ln \hat{Y}=\ln a+b \ln D+c \ln H$ & -3.764 & 1.991 & 0.124 & 0.907 & 0.329 & 0.168 & -2.192 \\
\hline \multirow[t]{3}{*}{ Leaves } & $\ln \hat{Y}=\ln a+b \ln D$ & -4.015 & 1.934 & - & 0.974 & 0.155 & 0.090 & -3.728 \\
\hline & $\ln \hat{Y}=\ln a+b \ln \left(D^{2} H\right)$ & 2.734 & 0.798 & - & 0.965 & 0.182 & 0.136 & -3.339 \\
\hline & $\ln \hat{Y}=\ln a+b \ln D+c \ln H$ & -3.787 & 2.048 & -0.282 & 0.975 & 0.156 & 0.086 & -3.689 \\
\hline \multirow[t]{3}{*}{ Total } & $\ln \hat{Y}=\ln a+b \ln D$ & -2.245 & 2.114 & - & 0.985 & 0.127 & 0.070 & -4.133 \\
\hline & $\ln \hat{Y}=\ln a+b \ln \left(D^{2} H\right)$ & 5.135 & 0.874 & - & 0.980 & 0.149 & 0.108 & -3.746 \\
\hline & $\ln \hat{Y}=\ln a+b \ln D+c \ln H$ & -2.266 & 2.103 & 0.025 & 0.985 & 0.129 & 0.070 & -4.066 \\
\hline \multicolumn{9}{|l|}{ M. azedarach } \\
\hline \multirow[t]{3}{*}{ Root } & $\ln \hat{Y}=\ln a+b \ln D$ & -3.211 & 2.091 & - & 0.993 & 0.096 & 0.058 & -4.690 \\
\hline & $\ln \hat{Y}=\ln a+b \ln \left(D^{2} H\right)$ & 3.863 & 0.847 & - & 0.990 & 0.111 & 0.091 & -4.332 \\
\hline & $\ln \hat{Y}=\ln a+b \ln D+c \ln H$ & -3.402 & 1.992 & 0.216 & 0.993 & 0.096 & 0.060 & -4.669 \\
\hline \multirow[t]{3}{*}{ Stem } & $\ln \hat{Y}=\ln a+b \ln D$ & -1.178 & 1.912 & - & 0.998 & 0.050 & 0.035 & -5.980 \\
\hline & $\ln \hat{Y}=\ln a+b \ln \left(D^{2} \mathrm{H}\right)$ & 5.294 & 0.775 & - & 0.994 & 0.077 & 0.065 & -5.061 \\
\hline & $\ln \hat{Y}=\ln a+b \ln D+c \ln H$ & -1.301 & 1.849 & 0.139 & 0.998 & 0.050 & 0.035 & -5.982 \\
\hline \multirow[t]{3}{*}{ Branches } & $\ln \hat{Y}=\ln a+b \ln D$ & -2.367 & 2.145 & - & 0.999 & 0.025 & 0.018 & -7.399 \\
\hline & $\ln \hat{Y}=\ln a+b \ln \left(D^{2} H\right)$ & 4.890 & 0.868 & - & 0.995 & 0.085 & 0.067 & -4.877 \\
\hline & $\ln \hat{Y}=\ln a+b \ln D+c \ln H$ & -2.375 & 2.141 & 0.009 & 0.999 & 0.025 & 0.018 & -7.333 \\
\hline \multirow[t]{3}{*}{ Leaves } & $\ln \hat{Y}=\ln a+b \ln D$ & -2.371 & 1.682 & - & 0.920 & 0.264 & 0.141 & -2.667 \\
\hline & $\ln \hat{Y}=\ln a+b \ln \left(D^{2} H\right)$ & 3.321 & 0.683 & - & 0.923 & 0.260 & 0.164 & -2.628 \\
\hline & $\ln \hat{Y}=\ln a+b \ln D+c \ln H$ & -2.813 & 1.454 & 0.497 & 0.923 & 0.264 & 0.154 & -2.632 \\
\hline \multirow[t]{3}{*}{ Total } & $\ln \hat{Y}=\ln a+b \ln D$ & -0.698 & 1.983 & - & 0.997 & 0.054 & $\mathbf{0 . 0 3 7}$ & -5.838 \\
\hline & $\ln \hat{Y}=\ln a+b \ln \left(D^{2} H\right)$ & 6.012 & 0.803 & - & 0.994 & 0.081 & 0.069 & -4.962 \\
\hline & $\ln \hat{Y}=\ln a+b \ln D+c \ln H$ & -0.827 & 1.916 & 0.145 & 0.998 & 0.053 & 0.037 & -5.837 \\
\hline S. macrophylla & & & & & & & & \\
\hline Root & $\ln \hat{Y}=\ln a+b \ln D$ & -2.947 & 2.028 & - & 0.987 & 0.109 & 0.084 & -4.435 \\
\hline & $\ln \hat{Y}=\ln a+b \ln \left(D^{2} H\right)$ & 3.958 & 0.732 & - & 0.984 & 0.122 & 0.097 & -4.146 \\
\hline & $\ln \hat{Y}=\ln a+b \ln D+c \ln H$ & -2.926 & 1.942 & 0.113 & 0.988 & 0.111 & 0.082 & -4.377 \\
\hline Stem & $\ln \hat{Y}=\ln a+b \ln D$ & -3.395 & 2.576 & - & 0.998 & 0.049 & 0.035 & -6.014 \\
\hline & $\ln \hat{Y}=\ln a+b \ln \left(D^{2} H\right)$ & 5.375 & 0.928 & - & 0.992 & 0.111 & 0.086 & -4.341 \\
\hline & $\ln \hat{Y}=\ln a+b \ln D+c \ln H$ & -3.432 & 2.724 & -0.195 & 0.999 & 0.047 & 0.032 & -6.080 \\
\hline Branches & $\ln \hat{Y}=\ln a+b \ln D$ & -4.160 & 2.529 & - & 0.974 & 0.198 & 0.113 & -3.237 \\
\hline & $\ln \hat{Y}=\ln a+b \ln \left(D^{2} H\right)$ & 4.454 & 0.915 & - & 0.975 & 0.195 & 0.128 & -3.208 \\
\hline & $\ln \hat{Y}=\ln a+b \ln D+c \ln H$ & -4.054 & 2.106 & 0.557 & 0.975 & 0.196 & 0.119 & -3.235 \\
\hline Leaves & $\ln \hat{Y}=\ln a+b \ln D$ & -4.185 & 2.330 & - & 0.985 & 0.138 & 0.090 & -3.962 \\
\hline & $\ln \hat{Y}=\ln a+b \ln \left(D^{2} H\right)$ & 3.751 & 0.842 & - & 0.983 & 0.146 & 0.110 & -3.781 \\
\hline & $\ln \hat{Y}=\ln a+b \ln D+c \ln H$ & -4.137 & 2.141 & 0.249 & 0.985 & 0.139 & 0.092 & -3.922 \\
\hline Total & $\ln \hat{Y}=\ln a+b \ln D$ & -2.344 & 2.446 & - & 0.995 & 0.081 & 0.051 & -5.019 \\
\hline & $\ln \hat{\mathrm{Y}}=\ln \mathrm{a}+\mathrm{b} \ln \left(\mathrm{D}^{2} \mathrm{H}\right)$ & 5.986 & 0.883 & - & 0.992 & 0.107 & 0.088 & -4.402 \\
\hline & $\ln \hat{Y}=\ln a+b \ln D+c \ln H$ & -2.326 & 2.373 & 0.096 & 0.995 & 0.082 & 0.053 & -4.964 \\
\hline T. grandis & & & & & & & & \\
\hline Root & $\ln \hat{Y}=\ln a+b \ln D$ & -4.728 & 2.671 & - & 0.990 & 0.132 & 0.062 & -4.054 \\
\hline & $\ln \hat{Y}=\ln a+b \ln \left(D^{2} H\right)$ & 4.435 & 1.071 & - & 0.978 & 0.197 & 0.137 & -3.189 \\
\hline & $\ln \hat{Y}=\ln a+b \ln D+c \ln H$ & -4.612 & 2.745 & -0.159 & 0.990 & 0.133 & 0.068 & -4.008 \\
\hline Stem & $\ln \hat{Y}=\ln a+b \ln D$ & -2.320 & 2.226 & - & 0.965 & 0.211 & 0.119 & -3.116 \\
\hline & $\ln \hat{Y}=\ln a+b \ln \left(D^{2} H\right)$ & 5.328 & 0.901 & - & 0.973 & 0.185 & 0.115 & -3.307 \\
\hline & $\ln \hat{Y}=\ln a+b \ln D+c \ln H$ & -2.938 & 1.830 & 0.847 & 0.973 & 0.189 & 0.068 & -4.008 \\
\hline Branches & $\ln \hat{Y}=\ln a+b \ln D$ & -3.833 & 2.556 & - & 0.987 & 0.145 & 0.076 & -3.865 \\
\hline & $\ln \hat{Y}=\ln a+b \ln \left(D^{2} H\right)$ & 4.933 & 1.023 & - & 0.971 & 0.216 & 0.143 & -3.000 \\
\hline & $\ln \hat{Y}=\ln a+b \ln D+c \ln H$ & -3.566 & 2.727 & -0.365 & 0.988 & 0.141 & 0.079 & -3.892 \\
\hline Leaves & $\ln \hat{Y}=\ln a+b \ln D$ & -3.893 & 1.900 & - & 0.916 & 0.285 & 0.145 & -2.513 \\
\hline & $\ln \hat{Y}=\ln a+b \ln \left(D^{2} H\right)$ & 2.621 & 0.759 & - & 0.900 & 0.311 & 0.179 & -2.270 \\
\hline & $\ln \hat{Y}=\ln a+b \ln D+c \ln H$ & -3.642 & 2.060 & -0.343 & 0.918 & 0.287 & 0.152 & -2.467 \\
\hline Total & $\ln \hat{Y}=\ln a+b \ln D$ & -2.039 & 2.369 & - & 0.989 & 0.124 & 0.068 & -4.170 \\
\hline & $\ln \hat{Y}=\ln a+b \ln \left(D^{2} H\right)$ & 6.094 & 0.954 & - & 0.985 & 0.144 & 0.098 & -3.807 \\
\hline & $\ln \hat{Y}=\ln a+b \ln D+c \ln H$ & -2.244 & 2.238 & 0.282 & 0.990 & 0.122 & 0.067 & -4.179 \\
\hline
\end{tabular}




\begin{tabular}{|c|c|c|c|c|c|c|c|c|}
\hline \multicolumn{9}{|l|}{ Total } \\
\hline \multirow[t]{3}{*}{ Root } & $\ln \hat{Y}=\ln a+b \ln D$ & -3.704 & 2.226 & - & 0.919 & 0.333 & 0.263 & -2.199 \\
\hline & $\ln \hat{Y}=\ln a+b \ln \left(D^{2} H\right)$ & -4.108 & 0.871 & - & 0.922 & 0.326 & 0.266 & -2.223 \\
\hline & $\ln \hat{Y}=\ln a+b \ln D+c \ln H$ & -3.983 & 1.920 & 0.562 & 0.923 & 0.325 & 0.260 & -2.241 \\
\hline \multirow[t]{3}{*}{ Stem } & $\ln \hat{Y}=\ln a+b \ln D$ & -2.946 & 2.367 & - & 0.864 & 0.472 & 0.384 & -1.502 \\
\hline & $\ln \hat{Y}=\ln a+b \ln \left(D^{2} H\right)$ & -3.493 & 0.940 & - & 0.895 & 0.416 & 0.348 & -1.738 \\
\hline & $\ln \hat{Y}=\ln a+b \ln D+c \ln H$ & -3.842 & 1.384 & 1.803 & 0.904 & 0.399 & 0.333 & -1.829 \\
\hline \multirow[t]{3}{*}{ Branches } & $\ln \hat{Y}=\ln a+b \ln D$ & -3.984 & 2.476 & - & 0.796 & 0.631 & 0.503 & -0.922 \\
\hline & $\ln \hat{Y}=\ln a+b \ln \left(D^{2} H\right)$ & -4.599 & 0.989 & - & 0.833 & 0.571 & 0.460 & -1.105 \\
\hline & $\ln \hat{Y}=\ln a+b \ln D+c \ln H$ & -5.142 & 1.205 & 2.331 & 0.852 & 0.540 & 0.451 & -1.223 \\
\hline \multirow[t]{3}{*}{ Leaves } & $\ln \hat{Y}=\ln a+b \ln D$ & -4.191 & 2.152 & - & 0.812 & 0.522 & 0.479 & -1.302 \\
\hline & $\ln \hat{Y}=\ln a+b \ln \left(D^{2} H\right)$ & 3.181 & 0.849 & - & 0.828 & 0.498 & 0.448 & -1.376 \\
\hline & $\ln \hat{Y}=\ln a+b \ln D+c \ln H$ & -4.751 & 1.539 & 1.126 & 0.829 & 0.499 & 0.442 & -1.383 \\
\hline \multirow[t]{3}{*}{ Total } & $\ln \hat{Y}=\ln a+b \ln D$ & -2.200 & 2.348 & - & 0.873 & 0.451 & 0.367 & -1.593 \\
\hline & $\ln \hat{Y}=\ln a+b \ln \left(D^{2} H\right)$ & 5.850 & 0.932 & - & 0.901 & 0.398 & 0.326 & -1.827 \\
\hline & $\ln \hat{Y}=\ln a+b \ln D+c \ln H$ & -3.037 & 1.430 & 1.684 & 0.908 & 0.385 & 0.322 & -1.902 \\
\hline
\end{tabular}

Note: *indicated that the $p$-value for all models was <0.001; lna, $\mathrm{b}$, and $\mathrm{c}$ were the fitted parameters; $R^{2}$ was the coefficient of determination; RMSE was root mean square error; $M A B$ was mean absolute bias; $A I C$ was Akaike information criterion; the best models for biomass prediction were printed in bold

\section{Allometric models for estimating biomass}

The results obviously showed that every allometric model had good fits $(p<0.001)$ (Table 5). However, the most accurate allometric equations for estimating biomass were different in each tree species. These findings were similar to the previous studies conducted in other forest sites (Maulana et al. 2016; Purwanto et al. 2015; Stas et al. 2017; Almuqu et al. 2019; Altanzagas et al. 2019). For example, the equation $\ln \hat{Y}=\ln a+b x \ln D$ was the best model for predicting biomass in each component and the total tree from $F$. moluccana. But, the model showed lower precision for estimating stem biomass in M. azedarach, $T$. grandis, and $S$. macrophylla. On the other hand, the equation $\ln \hat{Y}=\operatorname{lna}+\mathrm{b} \times \operatorname{lnD}+\mathrm{c} \times \ln \mathrm{H}$ was the most suitable to predict the biomass in branches, stem, and the total tree of $T$. grandis, but it generated smaller accuracy when it was used to estimate the root and leaf biomass (Table 5). Interestingly, the mean $\mathrm{R}^{2}$ values for all of the best models were more than $80 \%$. These findings documented that the best-selected models could explain more than $80 \%$ of the variation in the majority of the component and the total tree biomass. Those values were high enough since the stand attributes of community forests in the study area had great variation, particularly in the species composition and growth distribution.

The results of validation process showed there were similar patterns of estimated biomass values using our best models with other equations from the previous studies (Purwanto et al. 2015; Stas et al. 2017; Almuqu et al. 2019) (Figure 4). It indicated that our best-selected equations were reliable and could be utilized in the monitoring of forest biomass at community forests, mainly in the study area. Nevertheless, the value of estimated total biomass from our model was relatively lower than allometric equation recommended by Almuqu et al. (2019). In contrast, it provided higher estimation than model from Purwanto et al. (2015). It occurs because the accuracy of allometric equations for estimating tree biomass are also determined by certain factors, such as type of forest ecosystems, stand condition, management practice, and number of samples for direct measurement (destructive method) (Maulana et al. 2016; Nam et al. 2016; Altanzagas et al. 2019). This study discovered the utilization of equation $\ln \hat{Y}=-3.037+1.430 \ln \mathrm{D}+1.684 \ln \mathrm{H}$ was principally good enough to facilitate the rapid assessment of the total tree biomass from various species in the study area since it provided an accuracy around $90.8 \%$ (Table 5).

Similar to the previous studies, our allometric equation with one predictor variable, $\ln \hat{Y}=\ln a+b \times \ln D$, showed reasonably accurate biomass estimation for various species (Guendehou et al. 2012; He et al. 2018; Altanzagas et al. 2019), but the addition of tree height as independent variable in the equation resulted in more accurate biomass prediction ( $\mathrm{Li}$ and Zhao 2013; Dong et al. 2015; Chen et al. 2017). The equation $\ln \hat{Y}=\ln a+b \times \ln D+c \times \ln H$ was the most suitable to estimate biomass for various species. Besides providing high accuracy, this model was reliable to predict biomass from different tree species. It was also consistent with the previous studies which focused on the development of allometric models for mixed forest (Hosoda and Iehara 2010; Battulga et al. 2013; Altanzagas et al. 2019). Nevertheless, the biomass models resulted in this study had certain regional limitations since the equations were constructed based on the growth performance of stand in the study area. Therefore, the model requires further verification to be used in other areas.

In conclusion, this study clearly demonstrated that the biomass in each of four tree species of community forests in Madiun greatly varied in which the majority of biomass was accumulated in the stem. The best allometric equations for estimating individual tree biomass was different for each tree species. However, to facilitate the rapid assessment of tree biomass in the context of climate change mitigation, we recommended the use a general model, namely $\ln \hat{Y}=-3.037+1.430 \ln \mathrm{D}+1.684$. This model was reliable to estimate total individual tree biomass from various species in the study area with high accuracy. By adopting this equation, the forest managers of study site could conduct more efficient forest inventory and derive accurate data related to biomass. 


\section{ACKNOWLEDGEMENTS}

We are very grateful to village government in every location of community forest that allowed us to conduct this study in their area. We also express our gratitude to reviewers for suggestions to improve this article.

\section{REFERENCES}

Almuqu AA, Arponpong N, Boonyanuphap J. 2019. Biomass estimation and allometric equations for tree species in dry forest of East Nusa Tenggara, Indonesia. For Ideas 25 (2): 369-384.

Altanzagas B, Luo Y, Altansukh B, Dorjsuren C, Fang J, Hu H. 2019. Allometric equations for estimating the above-ground biomass of five forest tree species in Khangai, Mongolia. Forests 10 (8): 1-17. DOI: 10.3390/f10080661.

Arnhold E. 2018. R-environment package for regression analysis. Pesqu Agropecu Bras 53 (7): 870-873. DOI: 10.1590/S0100 204X2018000700012.

Baral S, Gautam AP, Vacik H. 2018. Ecological and economical sustainability assessment of community forest management in Nepal: A reality check. J Sustain For 37 (8): 820-841. DOI 10.1080/10549811.2018.1490188.

Battulga P, Tsogtbaatar J, Dulamsuren C, Hauck M. 2013. Equations for estimating the above-ground biomass of Larix sibirica in the foreststeppe of Mongolia. J For Res 24 (3): 431-437. DOI: 10.1007/s11676013-0375-4.

Chen D, Huang X, Zhang S, Sun X. 2017. Biomass modeling of larch (Larix spp.) plantations in China based on the mixed model, dummy variable model, and Bayesian hierarchical model. Forests 8 (8): 1-8. DOI: $10.3390 / \mathrm{f} 8080268$

Daba DE, Soromessa T. 2019. Allometric equations for aboveground biomass estimation of Diospyros abyssinica (Hiern) F. White tree species. Ecosyst Health Sustain 5 (1): 86-97. DOI: 10.1080/20964129.2019.1591169.

Dong L, Zhang L, Li F. 2015. Developing additive systems of biomass equations for nine hardwood species in Northeast China. Trees 29 1149-1163. DOI: 10.1007/s00468-015-1196-1.

Dong L, Zhang L, Li F. 2018. Additive biomass equations based on different dendrometric variables for two dominant species (Larix gmelini Rupr. and Betula platyphylla Suk.) in natural forests in the Eastern Daxing'an Mountains, Northeast China. Forests 9 (5): 1-24. DOI: $10.3390 / \mathrm{f} 9050261$

Ekoungoulou R, Niu S, Loumeto JJ, Ifo SA, Bocko EY, Mikieleko FEK, Guiekisse EDM, Senou H, Liu X. 2015. Evaluating the carbon stock in above-and below-ground biomass in a Moist Central African Forest. Appl Ecol Environ Sci 3 (2): 51-59. DOI: 10.12691/aees-3-2-4

Guendehou GHS, Lehtonen A, Moudachirou M, Mäkipää R, Sinsin B. 2012. Stem biomass and volume models of selected tropical tree species in West Africa. South For 74 (2): 77-88. DOI: 10.2989/20702620.2012.701432.

Hakamada R, Hubbard RM, Ferraz S, Stape JL. 2017. Biomass production and potential water stress increase with planting density in four highly productive clonal eucalyptus genotypes. South For 79 (3): 251-257. DOI: $10.2989 / 20702620.2016 .1256041$

He H, Zhang C, Zhao X, Fousseni F, Wang J, Dai H, Yang S, Zuo Q 2018. Allometric biomass equations for 12 tree species in coniferous and broadleaved mixed forests, Northeastern China. PLoS ONE 13 (1): 1-16. DOI: 10.1371/journal.pone.0186226.

Hosoda K, Iehara T. 2010. Aboveground biomass equations for individua trees of Cryptomeria japonica, Chamaecyparis obtusa and Larix kaempferi in Japan. J For Res 15: 299-306. DOI: 10.1007/s10310010-0192-y.

Jing D, Du Z, Wang M, Wang Q, Ma H, Liu F, Ma B, Dong Y. 2018 Regulatory effects of root pruning on leaf nutrients, photosynthesis, and growth of trees in a closed-canopy poplar plantation. PLoS ONE 13(5): e0197515. DOI: 10.1371/journal.pone.0197515.

Kebede B, Soromessa T. 2018. Allometric equations for aboveground biomass estimation of Olea europaea L. subsp. cuspidata in Mana Angetu Forest. Ecosyst Health Sustain 4 (1): 1-12. DOI 10.1080/20964129.2018.1433951.
Latifah S, Muhdi M, Purwoko A, Tanjung E. 2018. Estimation of aboveground tree biomass Toona sureni and Coffea arabica in agroforestry system of Simalungun, North Sumatra, Indonesia. Biodiversitas 19 (2): 620-625. DOI: 10.13057/biodiv/d190239.

Li H, Zhao P. 2013. Improving the accuracy of tree-level aboveground biomass equations with height classification at a large regional scale. For Ecol Manag 289: 153-163. DOI: 10.1016/j.foreco.2012.10.002.

Mate R, Johansson T, Sitoe A. 2014. Biomass equations for tropical forest tree species in mozambique. Forests 5 (3): 535-556. DOI: 10.3390/f5030535.

Maulana SI, Wibisono Y, Utomo S. 2016. Development of local allometric equation to estimate total aboveground biomass in Papua Tropical Forest. Indones J For Res 3 (2): 107-118. DOI: 10.20886/ijfr.2016.3.2.107-118.

Mendoza-Ponce A, Galicia L. 2010. Aboveground and belowground biomass and carbon pools in highland temperate forest landscape in Central Mexico. Forestry 83 (5): 497-506. DOI: 10.1093/forestry/cpq032.

Nam VT, Van Kuijk M, Anten NPR. 2016. Allometric equations for aboveground and belowground biomass estimations in an evergreen forest in Vietnam. PLoS ONE 11 (6): e0156827. DOI: 10.1371/journal.pone.0156827.

Nogueira Junior LR., Engel VL, Parrotta JA, Melo ACG, Ré DS. 2014. Equações alométricas para estimativa da biomassa arbórea em plantios mistos com espécies nativas na restauração da Mata Atlântica. Biota Neotrop 14 (2): e20130084. DOI: 10.1590/167606032013008413

Purwanto RH, Rohman, Maryudi A, Yuwono T, Permadi DB, Sanjaya M. 2015. Potensi biomasa dan simpanan karbon jenis-jenis tanaman berkayu di hutan rakyat Desa Nglanggeran, Gunungkidul, Daerah Istimewa Yogyakarta. Jurnal Ilmu Kehutanan 6 (2): 128-141. DOI: 10.22146/jik.5778. [Indonesian]

Rodríguez-Soalleiro R, Eimil-Fraga C, Gómez-García E， GarcíaVillabrille JD, Rojo-Alboreca A, Muñoz F, Oliveira N, Sixto H, Pérez-Cruzado C. 2018. Exploring the factors affecting carbon and nutrient concentrations in tree biomass components in natural forests, forest plantations and short rotation forestry. For Ecosyst 5 (35): 1-18. DOI: $10.1186 / \mathrm{s} 40663-018-0154-y$.

Setiahadi R. 2017. How significant is the existence of forest community contribution in GHG emissions reduction?. J Eng Appl Sci 12 (19): 4826-4830. DOI: 10.3923/jeasci.2017.4826.4830.

Stas MS, Rutishauser E, Chave J, Anten PR, Laumonier Y. 2017. Estimating the aboveground biomass in an old secondary forest on limestone in the Moluccas, Indonesia: Comparing locally developed versus existing allometric models. For Ecol Manag 389: 27-34. http://dx.doi.org/10.1016/j.foreco.2016.12.010.

Velázquez-Martí B, Fernández-González E, López-Cortés I, SalazarHernández DM. 2011. Quantification of the residual biomass obtained from pruning of trees in Mediterranean olive groves. Biomass Bioenergy 35 (7): 3208-3217. DOI: 10.1016/j.biombioe.2011.04.042.

Viera M, Rodríguez-Soalleiro R. 2019. A complete assessment of carbon stocks in above and belowground biomass components of a hybrid eucalyptus plantation in Southern Brazil. Forests 10 (7): 536. DOI: 10.3390/f10070536.

Wirabuana PYAP, Sadono R, Jurniarso S. 2019. Fertilization effects on early growth, aboveground biomass, carbon storage, and leaf characteristics of Eucalyptus pellita F. Muell. in South Sumatra. Jurnal Manajemen Hutan Tropika 25 (3): 154-163. DOI: 10.7226/jtfm.25.3.154 [Indonesian]

Wirabuana PYAP, Sadono R, Juniarso S. 2020. Planting depth management increases early growth, aboveground biomass, and carbon storage of Eucalyptus pellita at Ultisols in South Sumatra. J Degraded Mining Lands Manag 7 (4): 2253-2261. DOI: $10.15243 / \mathrm{jdmlm}$

Xue Y, Yang Z, Wang X, Lin Z, Li D, Su S. 2016. Tree biomass allocation and its model additivity for Casuarina equisetifolia in a tropical forest of Hainan Island, China. PLoS ONE 11 (3): e0151858. DOI: 10.1371/journal.pone.0151858.

Yue JW, Guan JH, Deng L, Zhang JG, Li G, Du S. 2018. Allocation patterns and accumulation potential of carbon stock in natural spruce forests in northwest China. Peer J 15 (5): e4859. DOI: $10.7717 /$ peerj.4859

Zeng W, Tang S. 2012. Modeling compatible single-tree aboveground biomass equations for masson pine (Pinus massoniana) in southern China. J For Res 23 (4): 593-598. DOI: 10.1007/s11676-012-0299-4. 
Zhang H, Wang K, Xu X, Song T, Xu Y, Zeng F. 2015. Biogeographical patterns of biomass allocation in leaves, stems, and roots in China's forests. Sci Rep 5: 1-12. DOI: 10.1038/srep15997.
Zhang X, Cao QV, Xiang C, Duan A, Zhang J. 2017. Predicting total and component biomass of Chinese fir using a forecast combination method. IForest Biogeosci-For 10 (4): 687-691. DOI: 10.3832/ifor2243-010. 